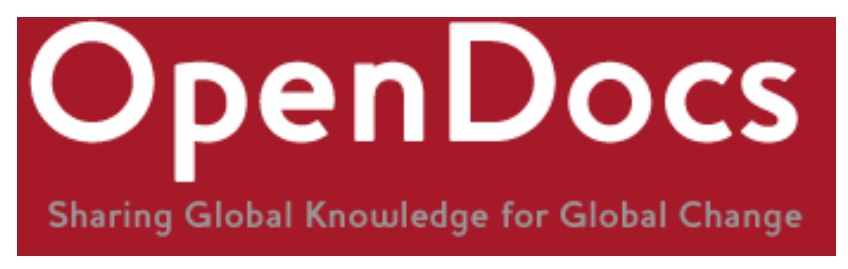

Title: Output and labour effects of GM maize and minimum tillage in a communal area of KwaZulu Natal.

Citation: Gouse, M., Piesse, J. and Thirtle, C. (2006,) Output and labour effects of GM maize and minimum tillage in a communal area of Kwa-Zulu-Natal, Journal of Development Perspectives, vol. 2, no. 2, pp. 71-86.

Official URL: http:/hdl.handle.net/10520/AJA20062184 41

More details/abstract: Insect resistant (Bt) white maize and minimum tillage are being adopted by smallholders in Hlabisa, KwaZulu-Natal. Bt cotton contains the genes controlling the production of a natural insecticide, Bacillus thuringiensis (Bt), which acts specifically on Lepidoptera, including bollworm in cotton and stem borers in maize, and is harmless to all other insects. A survey of 135 farms in 2003/4 is used in a stochastic frontier model to show that Bt seed did not increase yields per $\mathrm{kg}$ of seed and, because of its cost, made farmers 12 percent less efficient. This is due to unusually dry conditions, in which the stalk borer is not prevalent. Minimum tillage is being introduced to reduce erosion, but has more of an effect on production than $\mathrm{Bt}$, increasing yields by 12 percent and efficiency by 11 percent. However, it displaces labour, which may have adverse effects on poverty.

Version: Accepted version.

Terms of use: This work has been licensed by the copyright holder for distribution in electronic format via any medium for the lifetime of the OpenDocs repository for the purpose of free access without charge.

This is a download from OpenDocs at the Institute of Development Studies

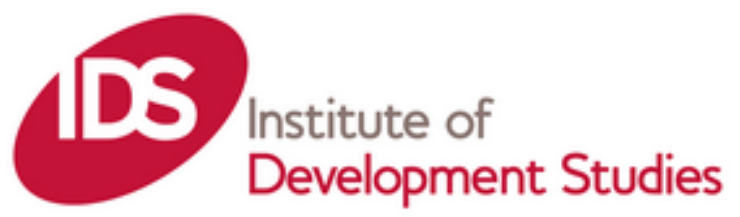




\title{
Output and Labour Effects of GM Maize and Minimum Tillage in a Communal Area of KwaZulu-Natal 1
}

\author{
Marnus Gouse \\ University of Pretoria, Pretoria \\ Pretoria 0002, South Africa \\ marnus.gouse@up.ac.za \\ Jenifer Piesse \\ King's College London \\ Department of Management \\ 150 Stamford St, London SE1 9HN, UK \\ Tel: 44 (0)297 8484164 \\ Email: jenifer.piesse@kcl.ac.uk \\ And \\ University of Stellenbosch, South Africa \\ Colin Thirtle (Corresponding Author) \\ Imperial College London \\ Centre for Environmental Policy \\ Prince Consort Road, London SW7 2AZ, UK \\ Tel: 44 (0)207 5949337 \\ Email: c.thirtle@ic.ac.uk \\ And \\ University of Pretoria, South Africa
}

\begin{abstract}
Insect resistant (Bt) white maize and minimum tillage are being adopted by smallholders in Hlabisa, KwaZulu-Natal. Bt cotton contains the genes controlling the production of a natural insecticide, Bacillus thuringiensis (Bt), which acts specifically on Lepidoptera, including bollworm in cotton and stem borers in maize, and is harmless to all other insects. A survey of 135 farms in 2003/4 is used in a stochastic frontier model to show that $\mathrm{Bt}$ seed did not increase yields per $\mathrm{kg}$ of seed and, because of its cost, made farmers $12 \%$ less efficient. This is due to unusually dry conditions, in which the stalk borer is not prevalent. Minimum tillage is being introduced to reduce erosion, but has more of an effect on production than $\mathrm{Bt}$, increasing yields by $12 \%$ and efficiency by $11 \%$. However, it displaces labour, which may have adverse effects on poverty.
\end{abstract}

JEL classification: $013,033, \mathrm{J43}$

Key words: Africa, KwaZulu-Natal, GM maize, minimum tillage

${ }^{1}$ Published in Journal of Development Perspectives. 2:2, 192-207 


\section{Output and Labour Effects of GM Maize and Minimum Tillage in a Communal Area of KwaZulu-Natal}

\section{Introduction}

This study reports on a survey of semi-subsistence maize production in a poor area of KwaZulu-Natal, conducted in 2003/4. The majority of output is consumed on the farm and an average of about $25 \%$ is marketed. It concentrates on the output and employment impacts of insect resistant Bt maize as well as minimum tillage, which is known locally as planting without ploughing (PWP) which is also being used in the area. The impact on performance is measured by simple partial productivity indices, which are output per kg of seed, per hectare of land and per hour of labour. The total effect, with respect to all inputs, is captured by comparing farm level efficiencies, relative to best practice, which is determined by a stochastic production frontier.

The paper proceeds as follows. The next section briefly outlines the history of GM maize in South Africa, describes the region, reviews the salient features of maize production using summary statistics and describes the data used in estimation. Section three uses partial productivity measures to analyze the output performance of the two new technologies and their impact on labour use. Section four outlines the stochastic frontier model, with inefficiencies explained by farm specific factors. It reports the results of the hypothesis tests for model selection, the stochastic frontier results and the relative efficiencies of the technologies. A brief conclusion follows.

\section{Background, Summary Statistics and Variable Definitions ${ }^{2}$}

Bt yellow maize has been produced in South Africa since the 1998/99 season and large-scale commercial farmers appear to have benefited from its adoption. Despite paying more for seeds, adopters enjoyed increased income over conventional varieties through savings on pesticides and increased yield due to better pest control. Irrigated and dryland commercial farms surveyed in Mpumalanga, Northern Cape, and the North West province enjoyed statistically significant yield increases of $11 \%$ and $10.6 \%$ respectively (at a 95\% confidence level) on average during the 1999/2000 and 2000/01 seasons (Gouse, Pray, Kirsten and Schimmelpfennig, 2005). Planting of GM maize increased from $14.6 \%$ of the total area in 2005 , to $29.4 \%$ in 2006 , according to the United States Department of Agriculture (2006). Much of this increase is due to white maize increasing from $8.6 \%$ of the total in 2005 to $28.8 \%$ in 2006.

Almost all of GM maize production is by commercial farmers, although small amounts are being grown in the communal areas of KwaZulu-Natal, including Hlabisa, which is situated just north

\footnotetext{
${ }^{2}$ For a survey of GM crops in developing countries see Qaim and Matuschke (2006). GM maize has been commercially released in Argentina, Honduras and Uruguay, but we know of no studies for these countries.
} 
of the Umfolozi game reserve, between Mtubatuba and Ulundi in north-eastern KwaZulu-Natal. The area has an annual average rainfall of more than $980 \mathrm{~mm}$, with $85 \%$ of the rain falling during the production season, with planting in November and harvesting in June. As much as $75 \%$ of harvested maize grain is kept for household consumption and chicken feed. The low proportion of the marketed surplus is indicative of the level of poverty in the region. Farmers cannot afford milling costs and use a hammer mill or crush their grain in a traditional way, to consume the maize as samp (stampmielies) with beans or with milk (amarhewu). The majority of households in the area own a small, old hand mills which produce fairly coarse mealies (maize meal).

The government extension officers have been recommending conservation tillage practises, or PWP, for some time, due to local erosion problems and because this play a major role in a maize production system in which transgenic herbicide tolerant technology is used. Monsanto has also been urging minimum tillage practises recently in some rural areas. Insect resistant or Bt white maize has been in use since 2001/2, when small quantities of free seed were supplied to small-scale farmers. Surveying 368 farmers in four provinces in 2001/2 and 104 farmers in two areas in northern KwaZuluNatal in 2002/3, Gouse et al (2006) found statistically significant yield increases with Bt maize of 32 $\%$ and $16.8 \%$ for the two seasons respectively. These yield increases are justifiable as they can be directly linked to stalk borer pressures in the two seasons.

In 2003/4 the survey covered 135 farms and data were collected on household characteristics, income, expenses, consumption, farming practices, production budgets and seed performance. The survey concentrated on accurate measures of output, including green mealies, which are eaten over the season, before the main harvest, and especially on labour use and area planted. There are complete records for all 135 producers, of whom 48 planted Bt only, 25 adopted PWP, two did both and 62 did neither. Farmers were surveyed with the help of enumerators who know the area and the farmers, and who had already been trained through their involvement in previous studies. Each respondent was visited seven times during the season, as Table 1 shows. Multiple visits were required to collect accurate labour data, rather than relying on farmer recall at the end of the season.

\section{Table 1}

The initial visit to each household in November/December 2003 entailed the collection of household information, in addition to labour data and input use for the first maize land preparation and planting activities. During a visit in February 2004, information was collected on pest incidence and on quantities of green mealies harvested, in addition to the ongoing collection of data on labour and input use. Previous studies showed that the March-May period is quiet, with few required activities. The major labour-using periods are during land preparation and planting and the first six weeks after planting for weeding and pesticide application. In May and June, data were collected on the quantities of maize harvested, again in addition to the ongoing labour data.

Table 2 reports the summary statistics for the sample, in terms of the variables used in estimation. Considerable care was taken to ensure that the variables were accurately measured. 
Output is in kgs of maize, with a mean of $401 \mathrm{kgs}$ per farm and a wide dispersion, ranging from $46 \mathrm{kgs}$ to $2660 \mathrm{kgs}$. Land area is in hectares, with some very small plots, an average maize area of only 0.378 hectares and even the largest farm has less than 5 hectares of maize. This range is normal in the disadvantaged areas of South Africa, as reported by the KwaZulu-Natal Income Distribution Survey. Furthermore, the preponderance of off farm activities necessitate the careful collection of data on labour actually used in farming. Total labour is measured in physical units, in this case, labour hours. The land is all marginal (in the sense of having low production potential) and there is little variation in quality or bio-physical characteristics, so there is no quality adjustment required in the analysis. The appropriate model is closer to that of Hansen (1979), which assumes unlimited supplies of marginal land, than to the Asian situation where maximizing yield is the main objective. Hansen's model is adapted to South Africa conditions by Thirtle, Piesse and Gouse (2005).

\section{Table 2}

The farmers' own estimates of the size of their plots were largely inaccurate, with gross overestimates. The mean reported plot size was 1.62 hectares, or over four times the measured areas. This bodes ill for studies that rely on information provided by farmers. The other production inputs are land preparation, seed and fertiliser costs, all measured in Rand. The land preparation costs are an aggregate of very different inputs. For the PWP farmers, it is herbicide costs, for others it is the cost of hiring a contractor to plough and for the rest it is the costs associated with preparation using donkeys or oxen, or own tractor use (only 3 farmers), or hand hoeing (skoffel). Seed cost is used rather than quantity, to allow for the fact that Bt seed costs over 50\% more than conventional seed. Fertiliser varies too, so it is included as a cost rather than a quantity.

The last two variables in Table 2 are farm-specific factors that are used to explain the efficiencies in the second part of the model. These are household size, measured as number of persons and the number of months that the household members managed to support themselves with the previous years maize harvest.

\section{Production and Labour Use Impacts of Bt and PWP}

\section{Output Effects}

The impact of the two new technologies on output is considered next and is the main point of the paper. The simplest partial productivity measures are analysed first in Table 3, beginning with output per hectare, with the area planted measured by the enumerators. The results show that for the full sample the average yield of maize grain is $1130 \mathrm{~kg}$, which is normal for these types of farms and only about half the two to three tonnes that the extension workers would like the farmers to achieve. The $\mathrm{Bt}$ average is $1392 \mathrm{~kg}$ and $38 \%$ higher than that for the non-Bt farms, which is $1007 \mathrm{~kg}$. This is frequently the only performance measure reported, for instance in the analysis of trial plot yields. Therefore, the question is does this mean that $\mathrm{Bt}$ is of value to these farmers? 


\section{Table 3}

Column two reports the yield per $\mathrm{kg}$ of seed, which is a more meaningful statistic for semisubsistence farmers on marginal land that is not particularly scarce. The farmers surveyed said that it is yield per bag of expensive seed that they care about. It shows that the Bt seed, which costs at least $50 \%$ more, gives the same output per $\mathrm{kg}$ of seed as conventional seed. The farmers are adamant that this is the appropriate test, not yield per hectare, since land is regarded as free, whereas the seed is expensive. The difference between output per hectare and output per $\mathrm{kg}$ of seed is explained by the planting density, shown in column three. This must be true as $\mathrm{Q} / \mathrm{A} \equiv \mathrm{Q} / \mathrm{S} * \mathrm{~S} / \mathrm{A}$ is an identity and indeed column three shows that S/A is 37\% higher for the Bt farms. Note that geometric (rather than arithmetic) means are used for these three measures, so that the identity holds in the individual mean values. All the other averages reported are arithmetic means.

This poor return to Bt seed is the result of very low pest pressure in a dry year, as in the previous season Bt yielded 16.8\% more per $\mathrm{kg}$ of seed (Gouse et al., 2006). Farmers selling the additional grain enjoyed an R39.00 income increase, but food deficit households gained R210. Thus, the poorest farmers, who are replacing purchased maize meal with the extra Bt maize that they produce, benefit the most. This demonstrates the need for more than one year of data. The next column shows that Bt uses the same amount of labour as conventional seed, which is also a function of the low pest pressure. All else being equal, the Bt seed should have saved labour used to spread pesticide granules, but there was so little damage to the non-Bt (conventional) crop that there is no significant effect.

The other new technology is PWP, which was used with non-Bt maize (except in two cases) and is analyzed in the last rows of Table 3. Although the main objective of the extension agents in recommending PWP was to reduce erosion, the first column shows that it actually increased yield per hectare by $12 \%$, which was not expected. In contrast with $\mathrm{Bt}$, this is because output per $\mathrm{kg}$ of seed increased by $15 \%$, while the next column shows that the seeding rate was actually slightly lower. In this case, the yield gain is combined with a $98 \%$ increase in labour productivity.

Table 3 also shows that the specification of the model must allow for these non-neutral factor saving biases of $\mathrm{Bt}$ and especially PWP, which must lead to different factor shares and output elasticities. With larger samples, it is possible to test whether the sub-samples can be pooled (Conradie, Cookson and Thirtle, 2006), but even with this limited number of observations, elasticities can be allowed to vary between technologies.

\section{Employment Effects}

The impact of GM crops on employment has attracted little attention to date, but this survey made a point of repeated visits in order to gather accurate labour input data. Experience with labour data based on farmer recall at the end of the season suggests margins of error as large as those for area planted. The data are reported in Table 4 according to task and the last column shows that the average 
farm used 250 hours of labour. The Bt technology is neutral with respect to labour use, but the PWP technology reduces the labour input by a $63 \%$, relative to the average for all farms. Table 4 shows labour savings across all tasks, but especially in land preparation and weeding, as expected.

\section{Table 4}

It is fortunate that this labour input reduction has been recorded in this year, as in the present season, PWP is being adopted in conjunction with Roundup Ready white maize. This is a herbicide tolerant GM variety, which is immune to the herbicide Roundup, allowing more effective weed clearance without deep ploughing. However, the results reported here indicate that the labour saving bias that will emerge can be attributed to PWP and is prior to the new GM technology.

\section{Choice of Model, Functional Form and Results}

The partial productivity measures used above are useful, but like any partial approach, they can be misleading, because they do not present the aggregate or total picture. To deal with this shortcoming, a stochastic frontier model is used, which generates farm level efficiencies that can be compared across technologies.

\section{The Model}

The survey by Battese (1992) shows that fitting frontier production functions to agricultural data is a well established approach. Stochastic frontiers, of the type originally suggested by Aigner, Lovell and Schmidt (1977), discriminate between random errors and farm level differences in efficiency. Battese and Coelli (1995) introduced the inefficiency model, in which the efficiency differences are simultaneously estimated from the stochastic frontier and explained by farm-specific variables. Their models incorporate tests that choose between functional forms and between frontier and mean response regression models.

The general form of the production frontier is

$$
\begin{aligned}
& Y_{i}=\alpha+\sum_{j} \beta_{x_{i j}}+\varepsilon_{i} \quad \text { where } \varepsilon_{i}=V_{i}-U_{i} \\
& \text { with } U \sim\left|N\left(0, \sigma_{U}^{2}\right)\right| \text { and } V \sim N\left(0, \sigma_{V}^{2}\right)
\end{aligned}
$$

The $V_{i}$ 's are independently and identically distributed random errors uncorrelated with the regressors, and the $\mathrm{U}_{i}$ 's are non-negative random variables associated with the technical inefficiency of the farm.

The technical efficiency of an individual farm is defined in terms of the ratio of the observed output to the corresponding frontier output, conditional on the levels of inputs used by that farm. Thus, the technical efficiency of farm $i$ in the context of the stochastic frontier production function is defined as 


$$
T E_{i}=\frac{Y_{i}}{Y_{i}^{*}}=\frac{f\left(x_{i}: \beta\right) \exp \left(v_{i}-u_{1}\right)}{f\left(x_{i}: \exp \left(v_{i}\right)\right.}=\exp \left(U_{i}\right)
$$

In Battese and Coelli's (1995) inefficiency model, the $\mathrm{U}_{\mathrm{i}} \mathrm{s}$, in equation (1) are defined as

$$
U_{i}=z_{i} \delta+W_{i}
$$

where $z_{i}$ is a vector of explanatory values associated with farm level technical inefficiencies in production, $\delta$ is a vector of unknown parameters to be estimated and the $\mathrm{W}_{\mathrm{i}} \mathrm{s}$ are the remaining errors. First, the functional form of the stochastic frontier is determined by testing the adequacy of the Cobb Douglas relative to the less restrictive translog. These frontier models are defined as

$$
Y_{i}=\beta_{0}+\sum_{j=1}^{n} \beta_{j} x_{j i}+\sum_{j=1}^{n} \sum_{k=1}^{n} \beta_{j k} x_{j i} x_{k i}+V_{i}-U_{i}
$$

where all of the variables are in logarithms, so that their coefficients are elasticities. If terms under the double summation are not significantly different from zero, the translog reduces to the Cobb Douglas. $\mathrm{Y}$ is maize output in physical terms and the independent variables $\left(\mathrm{x}_{\mathrm{i}}\right)$ are land, labour, land preparation costs, seed costs and fertiliser costs. This results in twenty independent variables in the translog due to the addition of five squared terms and ten cross product terms. This is already a lot to ask of 135 observations, but in the Cobb Douglas specification there are sufficient degrees of freedom to allow the model to be further developed to suit this particular problem, by including two intercept dummy variables, PWP and Bt seed, in order to determine the basic impact of these technologies. The elasticities can also be allowed to vary for the different technologies by including the products of the two intercept dummies and the five inputs. This gives

$$
Y_{i}=\beta_{0}+\sum_{t=1}^{2} \gamma_{t} D_{t}+\sum_{j=1}^{5} \beta_{j} x_{j i}+\sum_{t=1}^{2} \sum_{j=1}^{5} \lambda_{t j} D_{t} x_{j i}+V_{i}-U_{i} \quad \mathrm{i}=1, \ldots, 135
$$

which is still ambitious, as there are seventeen coefficients to estimate.

In both equations 4 and 5 , there are four explanatory variables $(z$, in 3$)$ in the inefficiency model. These are household size, self-sufficiency in maize, education (three levels) and a dummy variable denoting whether the household sold labour services during the period.

\section{Hypothesis Tests}

First, a series of hypothesis tests were conducted to select the functional form and to choose between the frontier model and a mean response production function. The results are in Table 5. Tests for the preferred functional form, where the null hypothesis $(\mathrm{H} 0)$ is that $\beta_{\mathrm{ij}}=0, \mathrm{i}, \mathrm{j}=1, \ldots, \mathrm{n}$, means that the Cobb-Douglas frontier is an adequate representation for these data. Generalized Likelihood Ratio (LR) tests show that this hypothesis is accepted as the test statistic is well below the critical value.

\section{Table 5}


Having selected the Cobb Douglas functional form, the next section of Table 5 reports the results of tests of the hypothesis that the technical efficiency effects are not simply random errors. The key parameter is $\gamma=\sigma_{\mathrm{u}}{ }^{2} /\left(\sigma_{\mathrm{u}}^{2}+\sigma_{\mathrm{v}}^{2}\right)$, which is the ratio of the errors in equation (1). Since $\gamma$ is defined between zero and one, if $\gamma=0$, technical inefficiency is not present, and if $\gamma=1$, there is no random noise. The null hypothesis is that $\gamma=0$, indicating that the mean response function (OLS) is an adequate representation of the data, whereas the closer $\gamma$ is to unity, the more likely it is that the frontier model is appropriate. If $\gamma$ is not significantly different from zero, the variance of the inefficiency effects ( $\mathrm{W}_{\mathrm{i}}$ in equation 3 ) is zero and the model reduces to a mean response function in which the inefficiency variables enter directly (Battese and Coelli, 1995). This test is unambiguous, with the value close to unity and the $t$ test indicating that the frontier is the appropriate model. The next column in this section reports the LR test values for the more powerful test with the null hypothesis that $\gamma=\delta_{0}=\delta_{\mathrm{i}}=0$, which means that in addition to $\gamma$ being insignificant, the inefficiency effects are not present in the model. The null hypothesis, $\mathrm{H}_{0}$, can be rejected at the $5 \%$ level, with degrees of freedom equal to the numbers of parameters set to zero.

\section{Results}

The tests establish that the Cobb Douglas function is an adequate representation of the unknown underlying production function, meaning that the cross products and squared terms did not improve the fit sufficiently to justify inclusion. They also show that the frontier is preferred to OLS and that the inefficiency terms have explanatory power. Table 6 reports the parameter estimates and t statistics for the preferred model. The small number of observation makes the model sensitive to the inclusion of variables that do not have explanatory power. Thus, both the intercept and slope dummies for the $\mathrm{Bt}$ technology were dropped, since these are not significantly different from zero, and their exclusion improved the log-likelihood statistic.

\section{Table 6}

The intercept and two of the slope dummies for PWP were significant and including all the PWP dummies minimized the log-likelihood statistic. This is the model that is reported, beginning in line 1) with the output elasticities for the inputs, when PWP was not used. Land and labour, which are the essential inputs, are both significant at the $1 \%$ level and land has an elasticity of 0.179 , meaning that a $1 \%$ increase in land will increase output by $0.18 \%$. The labour impact is a little greater, but the surprising result is the impact of the seed, which has an elasticity of 0.66 and thus has the biggest impact. By contrast, the land preparation cost elasticity is very small and not significantly different from zero. Although the fertiliser elasticity is very small, it is significant at the $10 \%$ level. The elasticities sum to 1.098, which indicates slight increasing returns to scale, so the farms are less than an optimal size. However, the sum is close to unity, so the elasticities should approximate factor shares in output. 
The intercept dummy for PWP in line 2) is positive and significant at the 5\% significance level, indicating that this technology does increase output, as well as cutting soil erosion, which was why it was originally introduced. This dummy is partly responsible for the insignificance of the land preparation variable, as PWP is a major cause of cost differences. The input specific terms are the elasticity adjustments for the PWP farmers. For land and labour and land preparation, these are negative, indicating that PWP reduces the impact and shares of these variables. For seed and fertiliser, the positive and significant coefficients indicate the opposite. Note too that the negatives sum to 0.39 and the positives to 0.36 , so that the shares add to much the same.

Line 3) shows the average elasticities for the 25 PWP farmers, which are the sum of the coefficients in lines 1) and 2). Thus, the value for land falls to 0.123 and the labour elasticity is reduced to near zero, while that for seeds increases to almost unity. Thus, although the adjustments are in the right direction, as PWP does reduce labour and land preparation, the results are too extreme, perhaps due to the small number of PWP observations.

The four variables that explain the inefficiencies are reported next. In the model, selling labour is not a cause (or a symptom) of inefficiency and neither is education, as both are not significantly different from zero. However, the significant negative effect of household size means this reduces inefficiency and the same is true of self sufficiency. Again, the causality may well be that the households that are more efficient achieve greater self sufficiency as a result.

The last row reports the efficiencies, to supplement the partial measures, which can obviously be misleading. These are a total measure, in that they take all the inputs into account. The higher cost of the $\mathrm{Bt}$ seed and its failure to increase output or reduce labour in this low pest pressure year is reflected in a $12 \%$ lower efficiency level for the Bt farmers. This is in marked contrast to all the previous studies of Bt cotton and maize in South Africa, such as Thirtle et al. (2003) and Gouse et al. (2006). This is due to the cost of the Bt seed, which can be established by running the model with seed quantity instead of cost. If this is done, there is no efficiency difference between Bt farms and those using conventional seed.

In contrast to the Bt result, PWP gives an $11 \%$ increase in efficiency, so that the PWP farmers are actually $17.5 \%$ more efficient than those who grew Bt. This is surprising, since PWP was introduced to cut erosion and the farmers did not expect efficiency gains.

\section{Conclusions}

This paper reports the results of analyzing a survey of smallholders growing white maize in Hlabisa, KwaZulu-Natal, using both Bt and PWP. The first result of note is that although the output per hectare for $\mathrm{Bt}$ is $38 \%$ higher, the output per $\mathrm{kg}$ of seed is the same as for the conventional seed. This suggests that for African smallholders, yield may not be a suitable measure of performance because land is not the most limiting factor. They report being more concerned with output per $\mathrm{kg}$ of seed, especially 
when it is expensive Bt seed. The second point is that a single year is not adequate for measuring performance. In this low pest pressure year, Bt gives no advantage and because of its higher cost causes the adopters to be inefficient relative to best practice. This study shows the need for several performance measures, based on estimates by trained enumerators and more than one year of data.

On the other hand, PWP, which was introduced to reduce erosion, does give both higher yields and higher efficiency levels. In this case, the yield gain of $15 \%$ per unit of seed is secondary to the main effect, which is saving in labour of 63\%, making PWP more efficient than any alternatives. However, this may not be an advantage, as many development economists would expect that less labour use will result in lower incomes for the poorest, whose incomes depend on selling labour services. This was always taken to be the case in labour abundant Asia, but in Sub-Saharan Africa it is not obvious that land is the scarce resource. Hence, maximizing yields may not be the objective and indeed labour productivity may matter more. This was perhaps true even before HIV/AIDS, which in an area such as KwaZulu-Natal may affect as much as $40 \%$ of the labour force, making any pronouncement on the suitability of labour saving technology highly dubious. It may be that PWP, which is now being combined with herbicide tolerant GM maize, will alleviate family labour shortages rather than reduce wage labour. Putting children into school, instead of subjecting them to the drudgery of weeding is hardly a bad idea, but future research has to identify the effects on employment by type before the welfare effects can be determined. 


\section{References}

Aigner D, Lovell K and Schmidt P (1977) Formulation and Estimation of Stochastic Frontier Models, Journal of Econometrics, 6: 21-37.

Battese, G. (1992) Frontier Production Functions and Technical Efficiency: a Survey of Empirical Applications in Agricultural Economics, Agricultural Economics, 7: 185-208.

Battese, G. and Coelli, T. (1995) A Model for Technical Inefficiency Effects in a Stochastic Frontier Production Function for Panel Data, Empirical Economics, 20: 325-332.

Coelli, T. (1994) FRONTIER Version 4.1: A Computer Program for Stochastic Frontier Production and Cost Function Estimation, Department of Econometrics, University of New England, Armidale, NSW.

Conradie, B,. Cookson, G. and Thirtle, C. (2006) Efficiency and Farm Size in Western Cape Grape Production: An Enquiry into Pooling Small Datasets, South African Journal of Economics, 74:2, 33443.

Gouse, M., Pray, C., Schimmelpfennig, D. and Kirsten, J. (2006) Three seasons of subsistence insect resistant maize in South Africa: Have small-holders benefited? AgBioForum, 9:1, 15-22.

Gouse, M., Pray, C., Kirsten, J.F., \& Schimmelpfennig, D. (2005) A GM subsistence crop in Africa: the case of Bt white maize in South Africa, International Journal of Biotechnology, 7:1/2/3, 84-94.

Hansen, B. (1979) Colonial Economic Development with Unlimited Supply of Land: A Ricardian Case, Economic Development and Cultural Change, 27: 611-27.

Kodde, D. and Palm, F. (1986) Wald Criteria for Jointly Testing Equality and Inequality Restrictions, Econometrica, 54:5, 1243-48.

Qaim, M and Matuschke, I. (2006) Impacts of Genetically Modified Crops in Developing Countries: A Survey, Quarterly Journal of International Agriculture, 44:3, 207-27.

Thirtle, C., Beyers, L., Ismaël, Y. and Piesse, J. (2003) Can GM-Technologies Help the Poor? The Impact of Bt Cotton in the Makhathini Flats of KwaZulu-Natal, World Development, 31: 717-32.

Thirtle, C., Piesse, J. and Gouse, M. (2005) Agricultural Technology, Productivity and Employment: Policies for Poverty Reduction in South Africa, Agrekon, 44:1, 37-59.

United States Department of Agriculture (2006) Pretoria's Biotechnology Annual with Minor Corrections, GAIN Report SF: 6029, www.fas.usda.gov/gainfiles/200608/146208636.pdf 
Table 1: Schedule of Visits to Sample Farmers in Hlabisa, KwaZulu-Natal

\begin{tabular}{llr}
\hline Month & Activities of farmers & Visits \\
October 2003 & Start-up meeting, training of enumerators, identify farmers & 1 \\
November 2003 & Land preparation, planting (+basal fertiliser), herbicide & 3 \\
$\begin{array}{l}\text { December 2003 } \\
\text { January 2004 }\end{array}$ & Weeding, top dressing, cutworm control & \\
February 2004 & Weeding, stalk borer control & \\
March 2004 & Green mealie harvesting & 1 \\
April 2004 & Quiet & 0 \\
May 2004 & Harvest & 2 \\
June 2004 & Harvest & 7 \\
TOTAL & & 7
\end{tabular}

Table 2: Data: Summary Statistics for Farms in Hlabisa in the 2003-4 Season

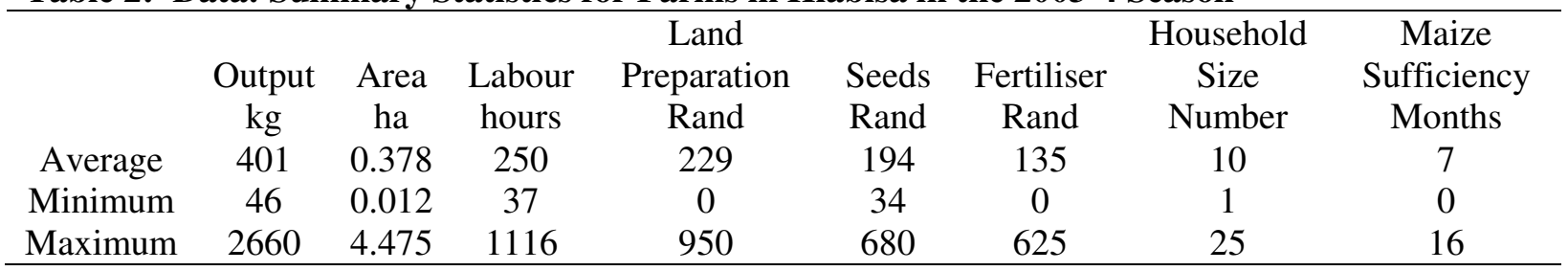

Table 3: Average Performance of Sample Farmers in Hlabisa in the 2003-4 Season

\begin{tabular}{ccccc} 
& Output per hectare, & $\begin{array}{c}\text { Output per kg of } \\
\text { Teed }\end{array}$ & $\begin{array}{c}\text { Kg of seed per } \\
\text { hectare }\end{array}$ & $\begin{array}{c}\text { Output per hour of } \\
\text { Labour }\end{array}$ \\
& $\mathrm{kg}$ & $\mathrm{Q} / \mathrm{S}$ & $\mathrm{S} / \mathrm{A}$ & $\mathrm{Q} / \mathrm{L}$ \\
All farms & 1130 & 57.18 & 19.76 & 2.114 \\
& & & & \\
Bt only & 1392 & 57.75 & 24.10 & 2.095 \\
Non Bt & 1007 & 56.87 & 17.70 & 2.125 \\
& & & & \\
PWP & 1234 & 63.97 & 19.28 & 3.544 \\
Non PWP & 1107 & 55.74 & 19.86 & 1.789 \\
\hline
\end{tabular}

Note: All but $\mathrm{Q} / \mathrm{L}$ are geometric means

Table 4: Analysis of Average Labour Use Impacts of Bt and PWP in Hlabisa in 2003-4 Season

\begin{tabular}{|c|c|c|c|c|c|c|c|c|}
\hline All & $\begin{array}{c}\text { Land } \\
\text { Preparation } \\
22\end{array}$ & $\begin{array}{c}\text { Planting } \\
36\end{array}$ & $\begin{array}{c}\text { Weeding } \\
102\end{array}$ & $\begin{array}{c}\text { Herbicide } \\
\text { Application } \\
0\end{array}$ & $\begin{array}{c}\text { Top } \\
\text { Dressing } \\
1\end{array}$ & $\begin{array}{c}\text { Pesticide } \\
\text { Application } \\
0\end{array}$ & Harvest & $\begin{array}{c}\text { Total } \\
\text { Labour } \\
250\end{array}$ \\
\hline $\mathrm{Bt}$ & 22 & 35 & 93 & 0 & 0 & 0 & 102 & 251 \\
\hline Non Bt & 21 & 36 & 106 & 1 & 1 & 1 & 83 & 248 \\
\hline $\begin{array}{l}\text { PWP } \\
\text { Non } \\
\text { PWP }\end{array}$ & 25 & 25 & 15 & 2 & 1 & 0 & $\begin{array}{l}70 \\
94\end{array}$ & $\begin{array}{c}93 \\
279\end{array}$ \\
\hline
\end{tabular}




\section{Functional Form Test}

\begin{tabular}{|c|c|c|c|c|c|c|}
\hline \multirow{2}{*}{$\begin{array}{c}\text { Parameter Restrictions: } \\
\qquad \beta_{\mathrm{jk}}=0 \\
\mathrm{H}_{0}: \mathrm{CD}, \mathrm{H}_{1} \text { : Translog }\end{array}$} & \multicolumn{2}{|c|}{$\begin{array}{l}\text { Log-Likelihood } \\
\text { values }\end{array}$} & \multicolumn{3}{|c|}{$\begin{array}{cc}\text { Degrees } & \chi_{15}^{2} \\
\text { of } & \text { Critical }\end{array}$} & \multirow{2}{*}{$\begin{array}{c}\text { Decision } \\
\text { Accept } \mathrm{H}_{0}-\mathrm{CD} \text { is } \\
\text { adequate }\end{array}$} \\
\hline & $\begin{array}{l}\mathrm{H}_{0}:- \\
97.39\end{array}$ & $\mathrm{H}_{1}:-90.34$ & 14.12 & 15 & 25.0 & \\
\hline & & Frontie & versus $\mathrm{O}$ & $\begin{array}{l}\text { LS Test } \\
\text { Degrees }\end{array}$ & & \\
\hline & $\gamma$ value & $\gamma$ t stat & $\begin{array}{l}\text { LLR test } \\
\text { statistic }\end{array}$ & $\begin{array}{l}\text { of } \\
\text { freedom }\end{array}$ & $\begin{array}{l}\chi_{15}^{2} \text { Critical } \\
1 \text { value at } 5 \%\end{array}$ & Decision \\
\hline $\begin{array}{l}\text { Irameter Restrictions: } \\
\qquad \mathrm{H}_{0}: \gamma=\delta_{\mathrm{i}}=0\end{array}$ & 0.999 & 114.951 & 12.34 & 6 & 11.911 & $\begin{array}{c}\text { Reject } \mathrm{H}_{0} \text { - frontier no } \\
\text { OLS }\end{array}$ \\
\hline
\end{tabular}

Note: The likelihood-ratio (LLR) test statistic, $\lambda=-2\left\{\log \left[\operatorname{Likelihood}\left(\mathrm{H}_{0}\right)\right]-\log \left[\operatorname{Likelihood}\left(\mathrm{H}_{1}\right)\right]\right\}$ has approximately $\chi_{v}^{2}$ distribution with $v$ equal to the number of parameters assumed to be zero in the null hypothesis.

Table 6: Stochastic Production Frontier and Inefficiency Model Results

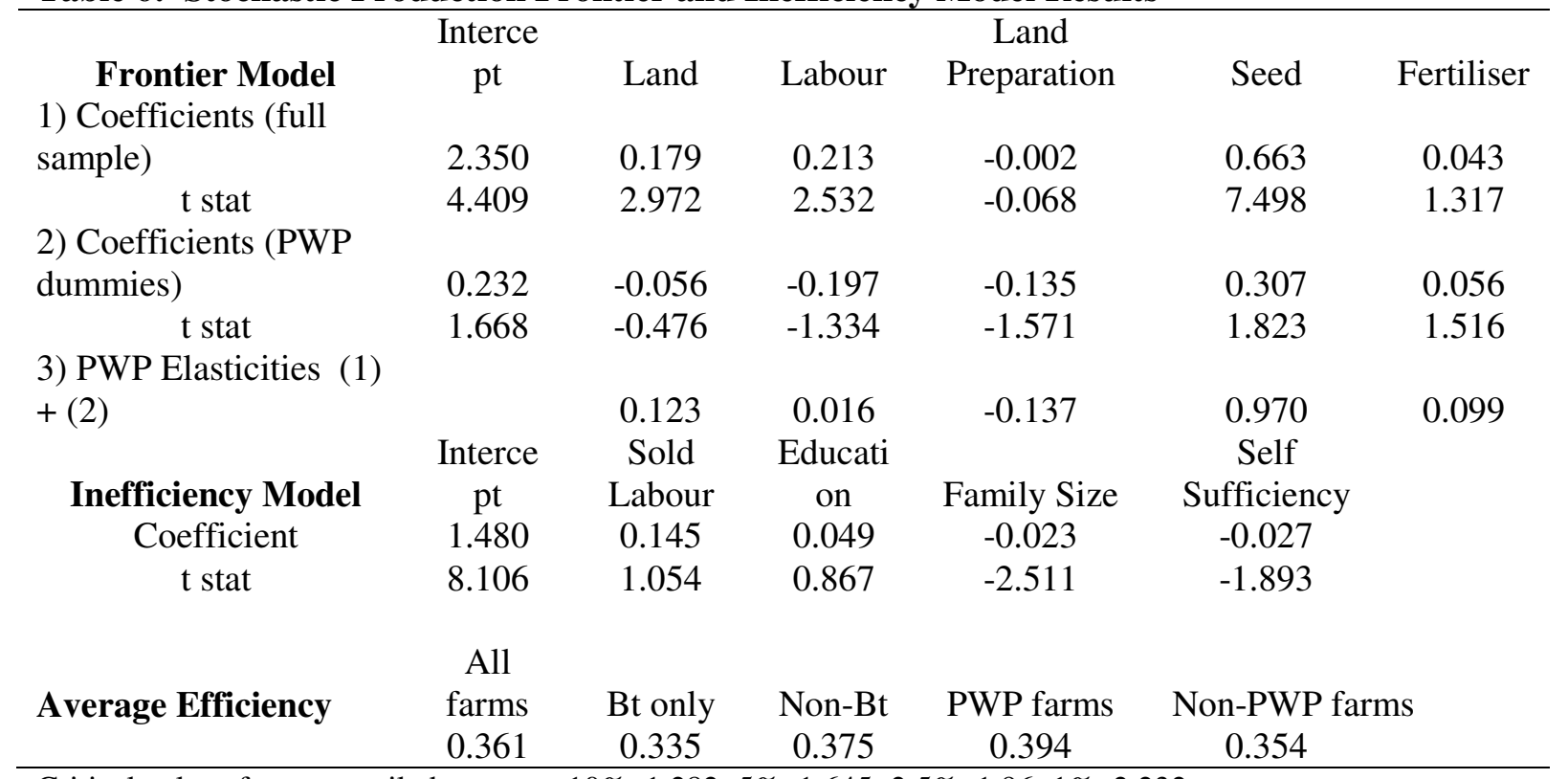

Critical values for a one tailed test are: $10 \%, 1.282 ; 5 \%, 1.645 ; 2.5 \%, 1.96 ; 1 \%, 2.232$

Note: As the null hypothesis involves the parameter $\gamma$, which as a ratio of two variances is necessarily positive, the test statistic has a mixed chi-squared distribution. The critical values are found in Kodde and Palm (1986). 